\title{
Surveillance \& Society \\ Covidiots as Global Acceleration of Local Surveillance Practices
}

Dialogue

\section{Daniel Trottier}

Erasmus University Rotterdam, The Netherlands

trottier@eshcc.eur.nl

\author{
Qian Huang
}

Erasmus University Rotterdam, The Netherlands

huang@eshcc.eur.nl

\section{Rashid Gabdulhakov}

Erasmus University Rotterdam,

The Netherlands

gabdulhakov@eshcc.eur.nl

\section{Introduction}

In 2020, hate-scrolling became embedded in a global public health mandate. When a restaurant employee was deemed responsible for a six-day lockdown in South Australia, politicians openly expressed their anger, with the state Premier claiming, "[w]e are absolutely livid with the actions of this individual and will be looking very carefully at what consequences there [are] going to be" (BBC 2020). International press fuelled this outrage, with tabloids noting the lack of legal justice. Such reporting published hateful comments from the restaurant's Facebook page. Yet they also cultivated a similar response against the employee in their own comments section. Indeed, we can question how these two sets of comments differ in terms of discourse or participants.

On a global scale, the COVID-19 pandemic compels civilians to drastically alter their conduct and to remain vigilant about the conduct of those around them. As cases spiked, the term covidiot emerged to capture a range of newly transgressive behaviours, including hoarding supplies, not wearing a mask, and travelling or congregating in public. Open denunciation of covidiots has become a prominent appeal from governments, with the mayor of Amsterdam instructing the public to report house parties and other novel infractions. In both public venues and the private sphere, politicians, journalists, and other influential figures urged their audiences to watch over and report behaviour that was deemed to be a public health risk. While such calls normally provoke controversy, they now encounter less friction among civilians. Indeed, these individuals have taken to platforms like Reddit and Twitter to provide unsolicited accounts of supposed public health risks. Digital media users are thus engaged in this watching independent of any state or press appeals, though they are, of course, dependent on platforms that make social life visible to others.

Current public health monitoring of and by individuals features three forms of convergence. First, covidiot surveillance marks a confluence of top-down efforts by states and the press and bottom up initiatives by civilians. Both states and civilians may share an interest in limiting the spread of the virus. Yet collective accord against the virus also feeds into surveillance that may otherwise provoke controversy, especially of vulnerable communities. Second, it marks a confluence between global patterns and local contexts: all countries are responding to a common threat. Yet just as we see localised mutations of the virus, peer surveillance also reflects local prejudices. Third, for civilians the coordinated responses to COVID-19 marks a merging of public health surveillance, urban security, and workplace surveillance, as well as the most 
mundane and intimate forms of lateral surveillance. Scrutiny of newly offensive behaviour applies to all contexts.

A broader category of antisocial behaviour demands novel forms of surveillance against civilians and amplification of ongoing monitoring. Below, we address the current public health crisis as a continued renegotiation of surveillance practices and a reliance on digitally mediated platforms. While rooted in prepandemic initiatives to either foster or contain civilian-based surveillance, covidiot scrutiny also marks both a cross-sector and cross-cultural expansion of these initiatives, in which terms of acceptable conduct (on cultural, ethical, and legal grounds) are relegated. After considering some global socio-political characteristics in which the pandemic emerged, we briefly account for peer-based scrutiny of so-called covidiots in a number of local settings. This includes the Netherlands, a highly digitized country where state measures have been lax, autocratic Central Asian stans, with varying degrees of digital divide challenges and where off- and online surveillance practices were at interplay, and China, where daily life has been heavily monitored through institutional and informal covid-related controls.

Before turning to regional contexts, we can consider global patterns that enable and amplify scrutiny of others. First, the pandemic not only brings a novel set of offences to seek out but also grievances against which to measure misconduct. The offence of the person being watched is all the more egregious in light of the sacrifices the watcher has to make: my neighbour's house party is measured against the social contact I gave up during the holidays. Our scrutiny is also shaped by feelings of insecurity. This not only includes safety concerns due to health risks but also coping with economic insecurity via a troubling job market and housing market, alongside political instability. Civilians may speculate that these impacts will outlast the virus, even though we lack a clear idea how the pandemic will end and what that ending will resemble, which in turns amplifies socio-economic fears. Watching over and denouncing others mitigates widespread feelings of powerlessness (Ingraham and Reeves 2016).

In terms of crisis management, government measures change on a weekly basis and are not always wellarticulated or consistently enforced. Earnest attempts by civilians to comply with public health measures are complicated as a result. Further, some authorities openly contradict local as well as international experts. Trump's spats with National Institute of Allergy and Infectious Diseases' Anthony Fauci are only the most spectacular examples of widespread contention. Among general populations, pre-existing social and political polarisation also map onto basic public health beliefs and commitments, such as wearing a face mask. One's willingness to follow guidelines touches upon deep ideological faultlines in many parts of the world, adding political baggage to peer scrutiny.

The global media landscape promotes scrutiny of others. News media frame their reporting of the spread in terms of individual misdeeds, notably if the individual in question is someone like a migrant worker, as in the opening example. This framing not only draws audiences to read their article but also to post denunciatory and hateful comments as well as to watch over peers as potential pandemic rule-breakers. Civilians also mobilise pre-existing networks, such as neighbourhood watch groups on WhatsApp and regional communities on Reddit. This occurs alongside novel fora such as Reddit's / $/$ /Covidiots. These groups are often independent of any state directive or coherent guidelines and may be rife with their own internal disputes, power struggles, and discriminatory biases in their monitoring of others. More broadly, 2020 saw a scaling up of digital literacies, as the only safe form of social contact is mediated. This not only increases the amount of data about ourselves and others that circulates but also widens the arsenal of tools and communities through which one can report their neighbours.

The Netherlands has seen an expansion of grounds upon which individuals, and especially groups of individuals, can be denounced. The term covidiot appears in the press to identify newly actionable behaviour as well as to legitimate scrutiny of and retaliation against those breaching public health measures. This scrutiny also features on digital platforms. Twitter users - including those employed in news media — upload images of ambiguously offensive content, such as lengthy queues at airports. Those photographed are not engaged in illegal behaviour, and the posts do not explicitly call for sanctions. Replies to the post not only 
criticize the decision to fly during a pandemic but also the decision to photograph this behaviour. Hashtags like \#aso020 (previously used to highlight woes of over-tourism in Amsterdam) are appropriated for novel offences such as refusing to wear face masks in public transit. Longstanding scrutiny of asocial behaviour easily accommodates covidiotry.

News platforms also remediate this social media content. In anticipation of stricter lockdown measures, the populist GeenStijl published a compilation of reports of queueing outside shops, often with accompanying photographs. Reports covered forty-five cities, spanning from Alphen to Zwolle. These sources were primarily from Twitter, including news accounts and users with modest followings. GeenStilj compiled and broadcasted these data during the afternoon of the queueing, generating extensive commentary from readers. The Dutch state has largely focused on the responsibilisation of individuals, issuing guidelines and "urgent advice" for civilians while legal implementations drag behind. This can be interpreted as a tacit endorsement of civilians watching over neighbours, though explicit calls are not uncommon.

Akbari (2021) questions the universality of applying "authoritarian" as a category that fits all "arbitrary surveillance" practices. Indeed, state surveillance in response to COVID-19 across post-Soviet Central Asian states varied in approaches, as did citizen-on-citizen vigilance. Tajikistan rushed to announce a victory over the virus as early as June 2020 (Eurasianet 2020). Turkmenistan, one of the most closed-off countries in the world, has yet to acknowledge any cases, despite claims that the country is "hit hard by the coronavirus pandemic," exemplified by the death of a Turkish diplomat in the capital Ashgabat in July (Pannier 2021). The highly repressive regime nevertheless enforced face masks (after first outlawing them) and, with the help of teachers and local government representatives, police officers patrol the streets and detain people without masks (RFE/RL 2020).

Kazakhstan, Kyrgyzstan, and Uzbekistan introduced strict lockdowns with block posts and armed military personnel surrounding major cities. In Kazakhstan, entire sections of apartment blocks with COVID-19positive residents had been welded shut to prevent them from leaving and spreading the virus (Sputniknews Kazakhstan 2020). A similar case occurred in neighbouring Kyrgyzstan (Reporter.kg 2020), although the state eventually switched to an absentee approach as people engaged in "grassroots" initiatives to combat the pandemic (Uran Kyzy 2020). Citizens coordinated on social media and messengers to collect funds for "protective gear for medical workers, as well as oxygen concentrators and saturation monitors" (Uran Kyzy 2020).

Some of the harshest surveillance measures were adopted in Uzbekistan, where the first COVID-19 case was detected in mid-March, after which the country shut its borders. The so-called "patient zero" flew in from Europe and gathered relatives to celebrate, allegedly contaminating them with the virus. This persona doctor - was eventually exposed online and reported to have received vitriolic comments and threats via social media. The state took an embodied approach to surveillance by placing National Guard officers not only in front of the doors of households where COVID-19 was detected but also in front of those where a family member had simply traveled abroad. Both types of households received stickers reading "quarantined" on them, leading to social stigma and shaming from fellow civilians for "bringing the virus" into the country. In some instances, the neighbours assisted National Guard officiers in identifying households. People flying into the country were placed in quarantine camps for fourteen days to prevent the spread of the virus. For unexplained reasons, state officials confiscated mobile phones and credit cards from such individuals during their stay at the camps (Sputniknews Uzbekistan 2020). As cases continued to spread across the country, the press took measures to protect the identities of newly infected individuals. However, neighbours would film ambulances arriving for people with COVID-19 and published their names and addresses on social media and messenger groups.

Just as Liu (2021) describes, the Chinese government exercises top-down control, surveillance, and strict regulations assisted by digital technologies in response to the COVID-19 pandemic. Methods include the nationally enforced Health Code, the comprehensive public transportation tracking system, and door-todoor community surveillance for citizens who have been to "risk areas." Since July 2020, when the Chinese 
government announced that the pandemic was under control (Jia, Niu, and Sun 2020), the official Sina Weibo accounts of local governments routinely report the travel routes of citizens who were confirmed COVID-positive. Even though such reports are anonymised, local citizens often identify the "virus-carriers" and publish their personal information on social media to "warn" their fellow citizens and shame people who "spread the virus and ruin our success in controlling the pandemic in China." In these cases, hashtags that are used by the government to inform the population (such as “\#成都确诊病例” [\#Chengdu confirmed case]) are adopted by vigilantes to name and shame COVID-19 patients. Speculation and vitriol spread through these posts based on travel routes, and gender-based violence is rampant. When the itinerary of a young woman in Chengdu who was confirmed positive was published on Sina Weibo, indicating that she visited various bars and clubs during one night, her supposed occupation and lifestyle became the focus of discussion.

Overseas Chinese students who return home are also common targets on social media. When these students share relevant information and their experiences online, they usually encounter criticism and shaming such as "you run away when our country needs your contribution, but you come back to spread the virus." The Chinese state has condemned such persecution via many fully or partially state owned media such as Xinhua News (Guo 2020). It is framed as a malevolent violation of citizens' privacy, harming patients who cooperate with the state's pandemic control functions by honestly reporting their activities. In addition to media discourses, the Chinese government also charged and detained a doctor in Hangzhou for giving away a COVID-19 patient's personal information (Wu and Ma 2021). Based on its recent stand against netizens openly denouncing civilians, it is no surprise that the Chinese government discourages such online peer surveillance. Yet we can further examine the factors behind such discouragement in the pandemic. Firstly, the Chinese state already has almost all of its citizens under constant surveillance through technologies such as the mandatory and ubiquitous ID system for travel and commerce. This monitoring is relatively wellperceived by Chinese citizens, especially when comparing the strategies and outcomes of pandemic control in China and the West (Liu 2021). Additionally, embodied peer surveillance prevails (CCDCP 2020). The routine announcement of new cases and relevant information also enables vigilantes to start their search and further exposure in the first place.

COVID-19 compels new forms of surveillance and amplifies existing practices. Depending on political context, civilians may or may not align their efforts to reduce viral spread. Yet a common pattern is the ease and enthusiasm with which they denounce others. Our global response to COVID-19 facilitates the convergence of surveillance of individuals by individuals, as so many disparate offences, and communities are united in their re-contextualisation through a public health crisis.

Press, states, and online communities are eager to attribute the prolonged crisis to individual behaviour. The internet makes it easy to direct collective scrutiny and ire at so-called covidiots. Yet systemic factors matter, including repeated mis-steps by governments and businesses not adopting recommendations to limit exposure. Civilians generally lack venues for critical engagement with government response. Occasional denunciation of governments often ends up targeting individuals for personal travel (such as Ontario's finance minister in Canada) and gatherings (such as Egypt's health minister) rather than failings in governance. Scrutiny of covidiots is sometimes contested, though pushback against it often manifests as a counter-denunciation of those involved, furthering peer surveillance. As public health risks subside, we can expect public scrutiny of others to remain a contested topic, both on public health and human rights grounds.

\section{References}

Akbari, Azadeh. 2021. Authoritarian Surveillance: A Corona Test. Surveillance \& Society 19 (1): 98-103.

BBC. 2020. Covid: Pizza Worker's "Lie" Forced South Australia Lockdown. BBC, November 20. https://www.bbc.com/news/world-australia-55011790 [accessed January 24, 2021].

CCDCP. 2020. Guanyu jiiaqiang xinxing guanzhuang bingdu ganran de feiyan yiqing shequ fangkong gongzuo de tongzhi [On strengthening the community control of the novice corona virus epidemic]. Chinese Center for Disease Control and Prevention. http://www.nhc.gov.cn/xcs/zhengcwj/202001/dd1e502534004a8d88b6a10f329a3369.shtml [accessed January $24,2021]$. 
Eurasianet. 2020. The Mystery of Tajikistan's “Win” on COVID-19. Eurasianet.org, June 9. https://eurasianet.org/the-mystery-oftajikistans-win-on-covid-19 [accessed January 24, 2021].

Guo, Yanhui. 2020. Chengdu quezhen nvhai beiwangbao? Yansu de yiqing fangkong burong tianluan! [The girl who is confirmed positive in Chengdu got cyber-bullied? Don't bring troubles to serious pandemic control!]. Xinhua News, December 9. http://www.xinhuanet.com/comments/2020-12/09/c 1126838254.htm [accessed January 24, 2021 ].

Ingraham, Chris, and Joshua Reeves. 2016. New Media, New Panics. Critical Studies in Media Communication 33 (5): $455-467$.

Jia, Xiaohong, Weikun Niu, and Leqi Sun. 2020. Jikong zhuanjiia: Quanguo gedi yiyou nengli jishi kongzhizhu yiiqing [Disease control experts: All local governments are able to contain the pandemic]. Xinhua News, July 22. http://www.xinhuanet.com/health/2020-07/22/c 1126269104.htm [accessed January 24, 2021].

Liu, Chuncheng. 2021. Chinese Public's Support for Covid-19 Surveillance in Relation to the West. Surveillance \& Society 19 (1): 89-93.

Pannier, Bruce. 2021. Why is the World Allowing Turkmenistan to Deny It Has the Coronavirus? Radio Free Europe/Radio Liberty, January 1. https://www.rferl.org/a/turkmenistan-coronavirus-fiction-turkey/31029363.html [accessed January 24, 2021].

Reporter.kg. 2020. Коронавирус. В Караколе заварили сваркой двери подъездов - видео [Coronavirus. Entrance doors welded in Karakol - video]. Reporter.kg, video, April 6. https://ru.reporter.kg/koronavirus-v-karakole-zavarili-svarkoi-dveripodieezdov-video/ [accessed January 24, 2021].

RFE/RL. 2020. Turkmenistan Toughens Face Mask Regime but Still Claims No Coronavirus. Radio Free Europe/Radio Liberty, November 11. https://www.rferl.org/a/turkmenistan-toughens-face-mask-regime-but-still-claims-no-coronavirus/30942504.html [accessed January 24, 2021].

Sputniknews Kazakhstan. 2020. Взятый на карантин подъезд заколотили в Караганде вместе с жильцами. [Тhe quarantined entrance was boarded up in Karaganda together with the residents]. March 30. https://ru.sputnik.kz/regions/20200330/13434058/karaganda-zamok-koronavirus.html [accessed January 24, 2021].

Sputniknews Uzbekistan. 2020. В Узбекистане у граждан на карантине конфискуют телефоны и банковские карты [Telephones and bank cards confiscated from citizens in quarantine in Uzbekistan]. March 24. https://uz.sputniknews.ru/society/20200324/13746744/V-Uzbekistane-u-grazhdan-na-karantine-konfiskuyut-telefony-ibankovskie-karty.html [accessed January 24, 2021].

Uran Kyzy, Aruuke. 2020. COVID-19 in Kyrgyzstan: National Unity and Frustration. The Diplomat, July 21. https:/thediplomat.com/2020/07/covid-19-in-kyrgyzstan-national-unity-and-frustration/ [accessed January 24, 2021].

$\mathrm{Wu}$, Shuaishua, and Jian Ma. 2021. Hangzhou mouyiyuan yishi yin guyi xielu liudiao baogao neirong bei xingzhengjuliu [A doctor from Hangzhou is detained for intentionally revealing personal information in the epidemiological investigation]. Xinhua News, January 7. http://www.xinhuanet.com/politics/2021-01/07/c 1126956340.htm [accessed January 24, 2021]. 